\title{
Inhibition of translation by cytotrienin A-a member of the ansamycin family
}

\author{
LISA LINDQVIST, ${ }^{1}$ FRANCIS ROBERT, ${ }^{1}$ WILLIAM MERRICK, ${ }^{2}$ HIDEAKI KAKEYA, ${ }^{3}$ CHRISTOPHER FRASER, ${ }^{4}$ \\ HIROYUKI OSADA, ${ }^{5}$ and JERRY PELLETIER ${ }^{1,6}$ \\ ${ }^{1}$ Department of Biochemistry, McGill University, Montreal, Quebec H3G 1Y6, Canada \\ ${ }^{2}$ Department of Biochemistry, School of Medicine, Case Western Reserve University, Cleveland, Ohio 44106, USA \\ ${ }^{3}$ Department of System Chemotherapy and Molecular Sciences, Graduate School of Pharmaceutical Sciences, Kyoto University, \\ Kyoto 606-8501, Japan \\ ${ }^{4}$ Department of Molecular and Cellular Biology, UC Davis, University of California, Davis, California 95616, USA \\ ${ }^{5}$ Chemical Biology Department, Advanced Science Institute, RIKEN, Wako-shi, Saitama 351-0198, Japan \\ ${ }^{6}$ The Rosalind and Morris Goodman Cancer Centre, McGill University, Montreal, Quebec H3G 1Y6, Canada
}

\begin{abstract}
The ansamycins are a diverse and often physiologically active group of compounds that include geldanamycin and rifamycin, inhibitors of heat shock protein 90 and prokaryotic DNA-dependent RNA synthesis, respectively. Cytotrienin A is an ansamycintype small molecule with potent antiproliferative and proapoptotic properties. Here, we report that this compound inhibits eukaryotic protein synthesis by targeting translation elongation and interfering with eukaryotic elongation factor $1 \mathrm{~A}$ function. We also find that cytotrienin A prevents HUVEC tube formation and diminishes microvessel formation in the chorioallantoic membrane assay. These results provide a molecular understanding into cytotrienin $A^{\prime}$ 's previously reported properties as an anticancer apoptosis-inducing drug.
\end{abstract}

Keywords: cytotrienin A; eEF1A; translation inhibitor; protein synthesis

\section{INTRODUCTION}

There is much interest in identifying and characterizing novel inhibitors of eukaryotic protein synthesis, both as tools to characterize the translation machinery and as drugs that can curtail malignant cell proliferation (Pelletier and Peltz 2007). There are several observations that suggest a high therapeutic index can be achieved by inhibiting translation in cancers. One vulnerability of cancer cells is at the level of ribosome recruitment, where mRNAs must compete with each other for limiting amounts of translation initiation factors (Duncan et al. 1987). Translation of mRNAs that are "weak" competitors for eukaryotic initiation factors (eIFs) are therefore more sensitive to small changes in the levels of these factors. Since several of the "weak" mRNAs characterized to date encode for antiapoptotic or prosurvival factors, their selective down-regulation prefer-

Reprint requests to: Jerry Pelletier, McIntyre Medical Sciences Building, Room 810, 3655 Promenade Sir William Osler, McGill University, Montreal, Quebec H3G 1Y6, Canada; e-mail: jerry.pelletier@mcgill.ca; fax: (514) 398-7384.

Article published online ahead of print. Article and publication date are at http://www.rnajournal.org/cgi/doi/10.1261/rna.2307710. entially curtails growth of tumor cells in preclinical cancer models (Graff et al. 2007; Cencic et al. 2009; Lucas et al. 2009). In addition, translation initiation inhibitors have been shown to exert antiangiogenic activities, a property that may contribute to their anti-cancer activity (Graff et al. 2007; Cencic et al. 2009). Additionally, the rapid reduction in levels of pro-oncogenic and pro-survival proteins having short half-lives (Chao et al. 1998; Nijhawan et al. 2003) occurs upon translation inhibition, and this can impair the growth of transformed cells. Higher translation rates also occur in human tumors and appear to be required to maintain their oncogenic state (Heys et al. 1991; Wendel et al. 2004). These latter two points may explain why some inhibitors of translation elongation show efficacy in preclinical cancer models as well as in the clinic (QuintasCardama et al. 2009; Robert et al. 2009).

The first step of translation elongation is catalyzed by eukaryotic elongation factor (eEF) 1A, which delivers the aminoacyl-tRNA (aa-tRNA) to the ribosomal A site, followed by GTP hydrolysis (provided that the proper codonanticodon interaction occurs). There are two isoforms of eEF1A, eEF1A1 and eEF1A2, which are encoded by separate genes and show 95\% identity. Both isoforms are thought to 
be functionally redundant for translation, although they are differentially expressed (Kahns et al. 1998) and both have been shown capable of acting as oncogenes in the appropriate setting (Thornton et al. 2003).

Here, we describe the characterization of a novel modulator of eEF1A from the ansamycin family. Cytotrienin A (Cyt A) is a natural product produced by Streptomyces sp., which has been previously reported to induce apoptosis in leukemia cell lines by activating c-Jun $\mathrm{N}$-terminal kinase (JNK), p38 mitogen-activated protein kinase (MAPK), and p36 myelin basic protein (MBP) kinase (Kakeya et al. 1998; Watabe et al. 2000). Here, we report that Cyt A inhibits translation elongation by interfering with eEF1A function. Our results provide molecular insight into Cyt A's previously reported properties as an anti-cancer compound.

\section{RESULTS}

\section{Cytotrienin A inhibits translation elongation}

During the course of a high-throughput screen to identify translation inhibitors (Novac et al. 2004), Cyt A (Fig. 1A) was identified as a "hit" that inhibited both cap-dependent (Firefly [FF] luciferase) and hepatitis C virus (HCV)-driven (Renilla [Ren] luciferase) translation in Krebs-2 extracts

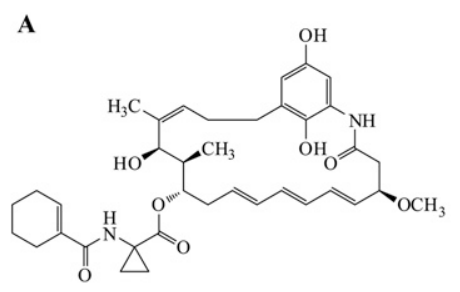

B

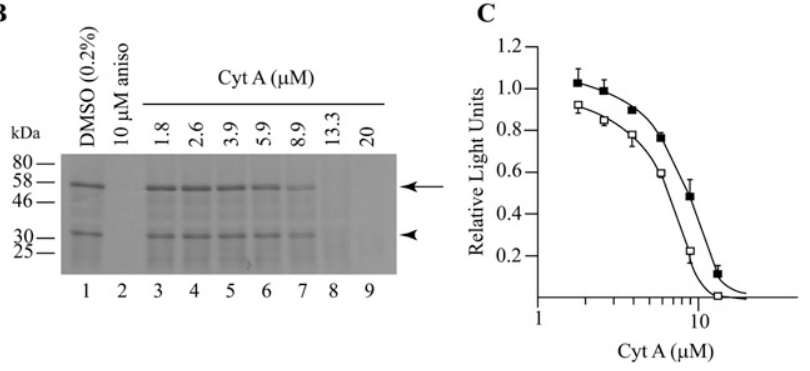

FIGURE 1. Cyt A inhibits eukaryotic translation. (A) Chemical structure of Cyt A. (B) Cyt A inhibits both cap-dependent and HCV IRES-driven translation in Krebs-2 extracts. In vitro translations were performed in the presence of $\left[{ }^{35} \mathrm{~S}\right]$ methionine and programmed with FF/HCV/Ren. DMSO, anisomycin (aniso), or Cyt A (lanes 3-9) were added to Krebs-2 extracts at the indicated concentrations. Proteins were separated by SDS-PAGE and visualized by autoradiography. The arrow and arrowhead denote Firefly and Renilla luciferase, respectively. $(C)$ Luciferase activity from translations performed in Krebs-2 extracts programmed with FF/HCV/Ren shown in B. Light units were set relative to the values obtained in the presence of vehicle (DMSO). The average of three measurements is shown with the SEM represented by error bars.
(Fig. 1B,C) and in rabbit reticulocyte lysate (RRL) (data not shown). Cyt A was also active in wheat-germ extracts, but did not significantly inhibit prokaryotic translation in $E$. coli S30 extracts at $50 \mu \mathrm{M}$ (data not shown). These results indicate that Cyt A inhibits both cap-dependent and IRESdependent translation. To determine whether the initiation phase of translation was affected by Cyt A, we performed ribosome binding experiments to assess the effects of Cyt A on 80 S complex formation (Fig. 2A). Cyt A was able to stabilize 80S complexes to a similar degree as cycloheximide (CHX) (Fig. 2A, left and right panels, respectively). As well, addition of the initiation inhibitor hippuristanol, followed by addition of Cyt $\mathrm{A}$ to the binding reactions, caused a decrease in $80 \mathrm{~S}$ complex formation (Fig. 2A, left), similar to if Hipp alone was present in the binding reactions (Fig. 2A, right). However, if Cyt A was present in the extract prior to the addition of Hipp, $80 \mathrm{~S}$ complexes were trapped to the same efficiency as observed for Cyt A (Fig. 2A, left). Consistent with these results, Cyt A inhibited the translation of poly(Phe) from poly(U) RNA (Fig. 2B). Taken together, these experiments strongly suggest that Cyt A targets translation elongation.

The elongation inhibitors homoharringtonine (HHT) and bruceantin (Bru) inhibit only newly initiated ribosomes during the first step of elongation and allow translating ribosomes to run-off mRNA templates (Pelletier and Peltz 2007; Robert et al. 2009). To determine whether Cyt A showed similar properties, we performed in vitro translation reactions in the presence of $\left[{ }^{35} \mathrm{~S}\right]$ methionine, where compound was added $5 \mathrm{~min}$ after the start of translation (Fig. 2C). A kinetic analysis was performed to quantitate the amount of product synthesized. Inhibition of translation by HHT is delayed by several minutes following its addition to a translating extract as polysomes run-off mRNA templates due to the reduced affinity of HHT for actively translating ribosomes (Fig. 2C; Chan et al. 2004). Addition of Cyt A immediately inhibited protein synthesis in a manner similar to $\mathrm{CHX}$. These results indicate that $\mathrm{Cyt}$ A affects translating ribosomes and does not allow polysome run-off.

\section{Cyt A modulates eEF1A-dependent aa-tRNA binding to the ribosome}

To better understand the mechanism by which Cyt A inhibits elongation, we analyzed its effects on tRNA binding to the ribosome, peptide bond formation, and translocation. We first tested whether Cyt A could inhibit the peptidyl transferase activity of the ribosome by monitoring the formation of $\left[{ }^{35} \mathrm{~S}\right]$ methionyl-puromycin. Cyt A did not inhibit peptidyl transferase activity under these conditions, unlike the known peptdyl transferase inhibitor HHT (Fig. 3A).

We next assessed whether Cyt A could affect binding of aa-tRNA to ribosomes in eEF1A-independent [high poly(U) 
A


B

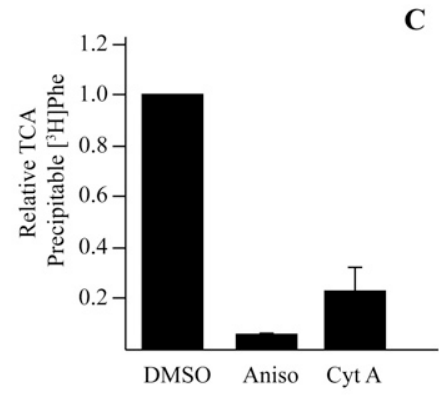

C

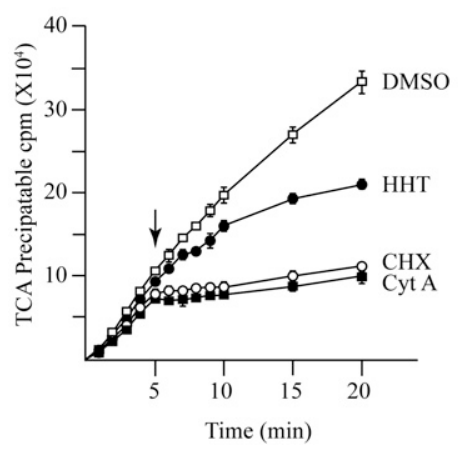

FIGURE 2. Cyt A inhibits translation elongation. (A) Cyt A does not inhibit translation initiation. Ribosome bindings were performed in RRL using ${ }^{32} \mathrm{P}$-labeled CAT RNA. Reactions were separated by centrifugation on $10 \%-30 \%$ glycerol gradients and fractions quantitated by scintillation counting. (Left) Ribosome bindings were performed in the presence of $50 \mu \mathrm{M}$ Cyt A alone, preincubated with $50 \mu \mathrm{M}$ hippuristanol (Hipp), followed by addition of $50 \mu \mathrm{M}$ Cyt A, or preincubated with $50 \mu \mathrm{M}$ Cyt A, followed by the addition of $50 \mu \mathrm{M}$ Hipp. (Right) Ribosome bindings were performed in the presence of $0.6 \mathrm{mM}$ CHX or $50 \mu \mathrm{M}$ Hipp. Both panels are part of the same experiment, but were separated for clarity. (B) Cyt A inhibits translation elongation. In vitro translations in RRL supplemented with $\left[{ }^{3} \mathrm{H}\right]$ phenylalanine and programmed with poly(U) RNA. Polypeptides were TCA precipitated and quantitated by scintillation counting. Counts were set relative to DMSO levels. The average of four measurements is shown with the SEM. $(C)$ Cyt A does not permit ribosome run-off. In vitro translation reactions of Krebs-2 extracts were allowed to proceed in the absence of compound for 5 min, after which time DMSO, HHT $(200 \mu \mathrm{M})$, CHX $(50 \mu \mathrm{M})$, or Cyt A $(20 \mu \mathrm{M})$ were added. Aliquots were taken at the indicated times, TCA precipitated, and quantitated by scintillation counting. The average of three measurements is shown with the SEM. The downward arrow indicates the point of addition of compound or vehicle.

RNA concentration] or eEF1A-dependent [low poly(U) RNA concentration] reconstituted systems. The ability of $\left[{ }^{14} \mathrm{C}\right] \mathrm{Phe}-$ tRNA $^{\text {Phe }}$ to bind ribosomes was not affected by Cyt A when binding was eEF1A independent (Fig. 3B), indicating that Cyt A does not compete with $\left[{ }^{14} \mathrm{C}\right] \mathrm{Phe}-\mathrm{tRNA}{ }^{\text {Phe }}$ for the ribosome. Under eEF1A-dependent conditions, the levels of ribosome-bound $\left[{ }^{14} \mathrm{C}\right] \mathrm{Phe}-\mathrm{tRNA}{ }^{\mathrm{Phe}}$ in the presence of GDP or GMPPNP were similar to those binding reactions lacking eEF1A in DMSO controls (Fig. 3C). [Also note that tRNA binding without eEF1A in this experiment is much lower than in the experiment presented in Fig. 3B, due to a $1000-$ fold decrease in poly(U) RNA template.] In the presence of GTP, the amount of $\left[{ }^{14} \mathrm{C}\right]$ Phe-tRNA ${ }^{\text {Phe }}$ bound to ribosomes increased significantly (Fig. 3C). Under this condition, both Cyt A and $\mathrm{CHX}$ decreased $\left[{ }^{14} \mathrm{C}\right]$ Phe-tRNA ${ }^{\text {Phe }}$ binding by $\sim 40 \%$, while Did B had no significant effect. The low amount of $\left[{ }^{14} \mathrm{C}\right]$ PhetRNA $^{\text {Phe }}$ binding to ribosomes observed in the presence of GMPPNP was increased when either Cyt A or Did B was present in the reactions (Fig. 3C). One interpretation of this result is that Cyt A stabilizes the ternary complex on the ribosome (see Discussion).

\section{eEF2-dependent translocation is inhibited by Cyt A only when aa-tRNA is delivered in an eEF1A-dependent manner}

The ability of Cyt A to affect eEF2dependent translocation was also investigated. After either nonenzymatic (as in Fig. 3B) or eEF1A-dependent aa-tRNA binding to the ribosome (with GTP, as in Fig. 3C), translocation was initiated by the addition of puromycin and eEF2. Under these conditions, CHX inhibited translocation regardless of whether $\left[{ }^{14} \mathrm{C}\right]$ Phe-tRNA ${ }^{\text {Phe }}$ binding was eEF1A dependent or eEF1A independent, whereas Cyt A inhibited translocation only when charged tRNA was loaded in an eEF1Adependent manner (Fig. 3D). Did B served as a positive control in the eEF1Adependent translocation assay and was found to inhibit this reaction (Fig. 3D).

\section{Cyt A inhibits neither ternary complex formation nor the GTPase activity of eEF1A}

The inhibitory effect in the presence of GTP and stimulatory effect in the presence of GMPPNP of Cyt A on tRNA binding could result from improper ternary complex formation (eEF1A:GTP:aatRNA). To determine whether Cyt A affects the ability of eEF1A to bind to GTP, we performed a UV cross-linking experiment with $\left[\alpha-{ }^{32} \mathrm{P}\right] \mathrm{GTP}$ in the presence or absence of Phe-tRNA $^{\text {Phe }}$ (Fig. 4A). We observed no significant change in the efficiency of GTP cross-linking to eEF1A in the presence of Cyt A (Fig. 4A, cf. lanes 2 and 5 with 1 and 4, respectively). Excess GTP competed for the radiolabeled $\left[\alpha-{ }^{32} \mathrm{P}\right] \mathrm{GTP}$ in this assay (cf. lane 3 and 6 with 1 and 4 , respectively). As well, Cyt A did not prevent eEF1A: $\left[{ }^{14} \mathrm{C}\right]-$ Phe-tRNA ${ }^{\text {Phe }}$ complex formation, as assessed by electrophoretic mobility shift assay (EMSA) (Fig. 4B). We investigated 
$\mathbf{A}$
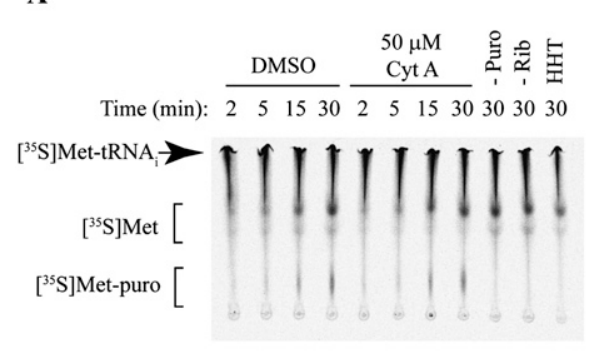


D

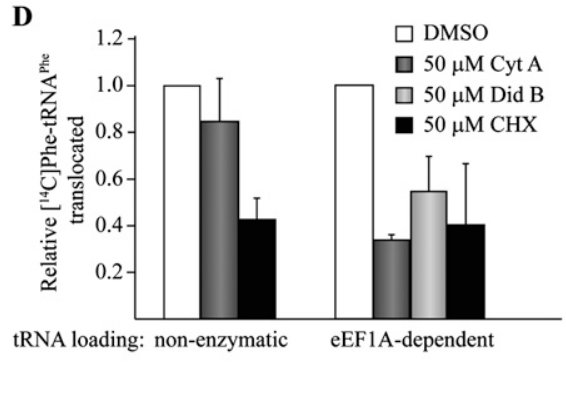

FIGURE 3. The effect of Cyt A on the steps of translation elongation. (A) Cyt A does not inhibit peptidyl transferase activity. $\left[{ }^{35} \mathrm{~S}\right] \mathrm{Methionine-}$ puromycin formation was monitored in the presence of purified $40 \mathrm{~S}$ and $60 \mathrm{~S}$ ribosomes using $\left.{ }^{35} \mathrm{~S}\right] \mathrm{Met}^{-\mathrm{RNA}} \mathrm{A}_{\mathrm{i}}$ and ribosomal high-salt wash from RRL. (Left) Aliquots of samples were taken at the indicated time points and separated by TLC. The position of migration of $\left[{ }^{35} \mathrm{~S}\right] \mathrm{Met}-\mathrm{puro}$, $\left[{ }^{35} \mathrm{~S}\right] \mathrm{Met}$, and $\left[{ }^{35} \mathrm{~S}\right]$ Met-tRNA $\mathrm{i}$ is indicated to the left. The addition of $50 \mu \mathrm{M}$ Cyt A, $40 \mu \mathrm{M}$ HHT, or the absence of puromycin (-Puro) or ribosomes $(-\mathrm{Rib})$ is indicated at top. (Right) Quantitation of $\left[{ }^{35} \mathrm{~S}\right]$ Met-puro production. The average of four experiments relative to the DMSO control at 30 min is shown. Note that values obtained from the reaction in the absence of puromycin were subtracted as background. The SEM is represented using error bars. (B) Cyt A does not inhibit eEF1A-independent $\left[{ }^{14} \mathrm{C}\right] \mathrm{Phe}-\mathrm{tRNA}{ }^{\text {Phe }}$ binding to $80 \mathrm{~S}$ ribosomes. Filter binding of $\left[{ }^{14} \mathrm{C}\right] \mathrm{Phe}-\mathrm{tRNA}{ }^{\mathrm{Phe}}$ was performed with purified 80 S ribosomes, $0.4 \mathrm{mg} / \mathrm{mL}$ poly(U) RNA, and either DMSO, $50 \mu \mathrm{M}$ Cyt A, or $50 \mu \mathrm{M}$ CHX. The average of four experiments is shown with the SEM indicated by error bars. $(C)$ Cyt A modulates eEF1A-dependent $\left[{ }^{14} \mathrm{C}\right]$ Phe-tRNA ${ }^{\text {Phe }}$ binding to $80 \mathrm{~S}$ ribosomes. Filter binding of $\left[{ }^{14} \mathrm{C}\right]$ Phe-tRNA ${ }^{\text {Phe }}$ with purified $80 \mathrm{~S}$ ribosomes, and $0.4 \mu \mathrm{g} / \mathrm{mL}$ poly(U) RNA in the presence of either DMSO, $50 \mu \mathrm{M}$ Cyt A, 50 $\mu \mathrm{M}$ DidB, or $50 \mu \mathrm{M}$ CHX. The presence of eEF1A and nucleotide is indicated. The average of three to six measurements is shown with SEM indicated by error bars. $(D)$ eEF2-dependent translocation of $\left[{ }^{14} \mathrm{C}\right]$ Phe-tRNA ${ }^{\text {Phe }}$ is inhibited by Cyt A only when aminoacyl-tRNA is loaded in an eEF1A-dependent manner. Following nonenzymatic or eEF1A-dependent tRNA binding (as described in $B$ and $C$ with GTP, respectively), eEF2 was added to the reaction with puromycin. The amount of puromycin-active $\left[{ }^{14} \mathrm{C}\right] \mathrm{Phe}-\mathrm{tRNA}{ }^{\mathrm{Phe}}$ was extracted with ethyl aceteate and quantitated by scintillation counting. tRNA already bound to the P-site was subtracted from these values (see Materials and Methods) and set relative to the DMSO control. The average of two to four experiments is shown with the SD.

whether Cyt A affects the GTPase activity of eEF1A and found no evidence to this effect (Fig. 4C). We conclude that Cyt A does not interfere with ternary complex formation.

\section{Cellular protein synthesis is inhibited by Cyt A}

$\left[{ }^{35} \mathrm{~S}\right]$ Methionine/cysteine labeling of HeLa cells was inhibited by Cyt A, whereas DNA and RNA synthesis was not dramatically affected (Fig. 5A). Inhibition of translation was reversible and showed almost complete recovery by $6 \mathrm{~h}$ after removal of the compound (Fig. 5B). The polysome profile of cells exposed to Cyt A for $1 \mathrm{~h}$ showed a similar to slight increase in polysomes compared with those isolated from cells exposed to vehicle (DMSO) (Fig. 5C). When hippuristanol was added during the last $30 \mathrm{~min}$ of Cyt $\mathrm{A}$ treatment, polysomes were still present, unlike what was observed when cells were exposed to only hippuristanol
(Fig. 5C, left). Cells treated with HHT, which is known to allow ribosome run-off, showed an absence of polysomes (Fig. 5C, right). This data is consistent with Cyt A causing stalling of translating ribosomes and allowing their accumulation on mRNA templates.

\section{Antiangiogenic properties of Cyt A}

Inhibition of translation has been shown to impair angiogenesis and has been suggested as a mechanism by which they function as anti-cancer therapeutics (Taraboletti et al. 2004; Graff et al. 2007; Cencic et al. 2009). We therefore tested whether Cyt A might have similar properties. To examine this, we utilized a HUVEC tube formation assay, which has been previously used to mimic some aspects of angiogenesis (Kubota et al. 1988; Graff et al. 2007; Cencic et al. 2009). The inhibition of tube formation with Cyt $A$ was dose dependent (Fig. 6A,B) at concentrations where 
A

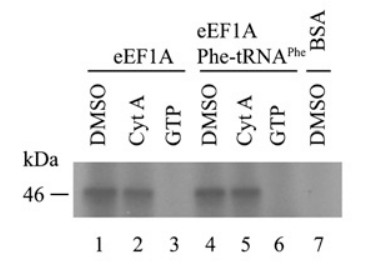

B



C

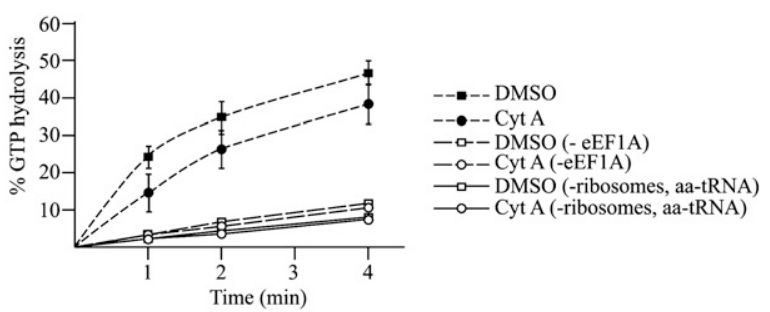

FIGURE 4. Cyt A does not affect ternary formation. (A) Cyt A does not inhibit GTP binding to eEF1A. Purified eEF1A (1 $\mu \mathrm{g})$ was UV cross-linked to $\left[\alpha^{32} \mathrm{P}\right]$ GTP in the presence (lanes 4-7) or absence (lanes 1-3) of Phe-tRNA ${ }^{\text {Phe }}$ and $50 \mu \mathrm{M}$ Cyt A or $1 \mathrm{mM}$ unlabeled GTP. Reactions were treated with RNase A, separated by SDS-PAGE, and visualized by autoradiography. (B) Cyt A does not affect $\left[{ }^{14} \mathrm{C}\right] \mathrm{Ph}_{\mathrm{Ph}}$-tRNA ${ }^{\text {Phe }}$ binding to eEF1A. Increasing amounts of eEF1A were incubated with $\left[{ }^{14} \mathrm{C}\right] \mathrm{Phe}-\mathrm{tRNA}{ }^{\mathrm{Phe}}$ in the presence of DMSO, $50 \mu \mathrm{M}$ Cyt A, or unlabeled Phe-tRNA ${ }^{\text {Phe }}$ competitor. EMSAs were performed on $6 \%$ polyacrylamide gels and visualized by autoradiography. The position of migration of free $\left[{ }^{14} \mathrm{C}\right] \mathrm{Phe}-$ tRNA $^{\text {Phe }}$ and complexes are indicated to the left. $(C)$ Cyt A does not affect the GTPase activity of eEF1A. eEF1A and $\left[\gamma-{ }^{32} \mathrm{P}\right] \mathrm{GTP}$ were incubated with $40 \mathrm{~S}$ and $60 \mathrm{~S}$ ribosomes and Phe-tRNA ${ }^{\text {Phe }}$ in the presence of $50 \mu \mathrm{M}$ Cyt A or DMSO. GTPase activity was also measured in the absence of eEF1A or without ribosomes or Phe-tRNA ${ }^{\text {Phe }}$. The average of three to four measurements is shown with the SEM represented as error bars.

general translation was inhibited by $>90 \%$, (Fig. 6C, open circles) similar to effects observed with silvestrol (Silv), a previously reported translation initiation inhibitor with antiangiogenic properties (Fig. 6A; data not shown) (Cencic et al. 2009). Importantly, cells remained viable under these conditions (Fig. 6C, squares). We also tested the ability of Cyt A to inhibit angiogenesis in the more physiological chorioallantoic membrane (CAM) assay. Cyt A inhibited new vessel growth in a dose-dependent manner (Fig. 6D), similar to the inhibitor of VEGF receptor tyrosine kinase Semaxanib (SU5416) (Riboldi et al. 2005).

\section{DISCUSSION}

Ansamycins form a diverse family of compounds exerting a number of physiological effects on mammalian and viral systems (Isaacs et al. 2003; Floss and Yu 2005). In this study, we identified a member of this family as an inhibitor of eukaryotic translation elongation. Other ansamycins such as rifabutin and 17-AAG did not inhibit protein synthesis in vitro in Krebs-2 extracts at $50 \mu \mathrm{M}$ (data not shown), indicating that this is not a general property of this group of compounds.

Increasing evidence links deregulated protein synthesis and cancer growth (Lindqvist and Pelletier 2009). Indeed, two inhibitors of elongation (HHT and a derivative of Did B) have advanced to clinical trials (Le Tourneau et al. 2007; Quintas-Cardama et al. 2007). In addition, we have previously shown that inhibitors of elongation can sensitize select tumors to the pro-apoptotic properties of the clinical agent doxorubicin (Robert et al. 2009). Inhibition of translation could, in principle, suppress drug resistance by curtailing the synthesis of antiapoptotic proteins and/or drug transporters. Leukemic cell lines have been previously shown to be more sensitive to Cyt A-induced apoptosis compared with other tumor cell lines, supporting a potential therapeutic use of Cyt $\mathrm{A}$ in blood cancer treatment
(Watabe et al. 2000). Here, we show that Cyt A inhibits protein synthesis in cell lines that were previously shown to be resistant to Cyt A-induced apoptosis (Fig. 5A) as well as in nontransformed HUVECs (Fig. 6C). Indeed HeLa, HUVEC, and Jurkat (a leukemia cell line previously shown to undergo apoptosis after a 24-h exposure to Cyt A $\left[\mathrm{IC}_{50}=\right.$ $13.87 \mathrm{nM}$ ]; Watabe et al. 2000) cells all had very similar $\mathrm{IC}_{50} \mathrm{~S}$ with respect to translation inhibition (data not shown). These results suggest that the differential sensitivity of different cell lines to the apoptotic response is not due to a difference in sensitivity to Cyt A-induced protein synthesis inhibition but may depend on intrinsic factors that link the apoptotic response to the translation apparatus. We demonstrate that translation inhibition occurs well before apoptosis can be detected and, therefore, must precede the apoptotic response (Fig. 6C). The fact that Cyt A induces apoptosis more readily in leukemia is consistent with reports that B-cell and leukemia-cell lines also are more sensitive to the translation initiation inhibitor silvestrol compared with other cell types (Monks et al. 1991; Lucas et al. 2009).

Translation elongation can be inhibited in an eEF1Adependent manner also by interfering with ternary complex formation (eEF1A:GTP:aminoacyl-tRNA). Indeed, several antibiotics target this step, including GE2770A and pulvomycin (Heffron and Jurnak 2000; Andersen et al. 2003). This mechanism is in contrast to that of Cyt A (Fig. $4 \mathrm{~A}, \mathrm{~B})$. Pulvomycin is known to increase the GTPase activity of EF-Tu, the bacterial homolog of eEF1A (Andersen et al. 2003), while both Did B and Cyt A do not alter GTPase activity of eEF1A to any significant extent (Fig. 4C; Crews et al. 1994; Ahuja et al. 2000). Therefore, the mechanism of action of Cyt A does not seem to be reminiscent of these EF-Tu-targeting inhibitors.

Cyt A stalled polyribosomes on mRNA templates and inhibited translating ribosomes, similar to what has been reported for the translation elongation inhibitors CHX and 
A

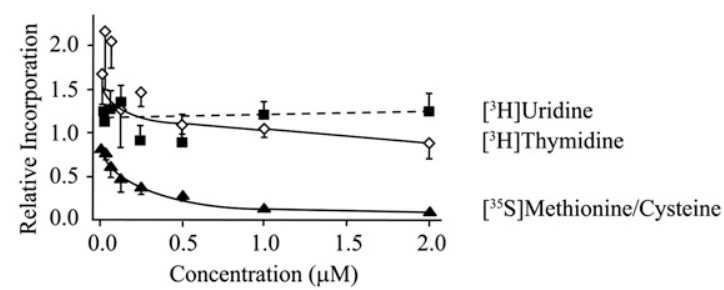

B

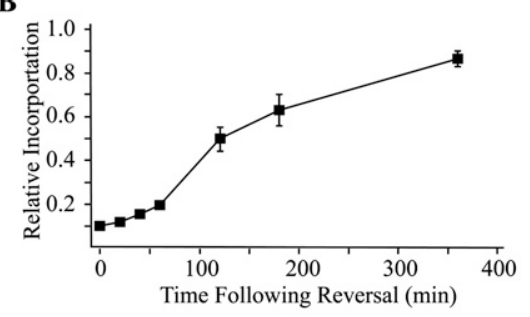

C
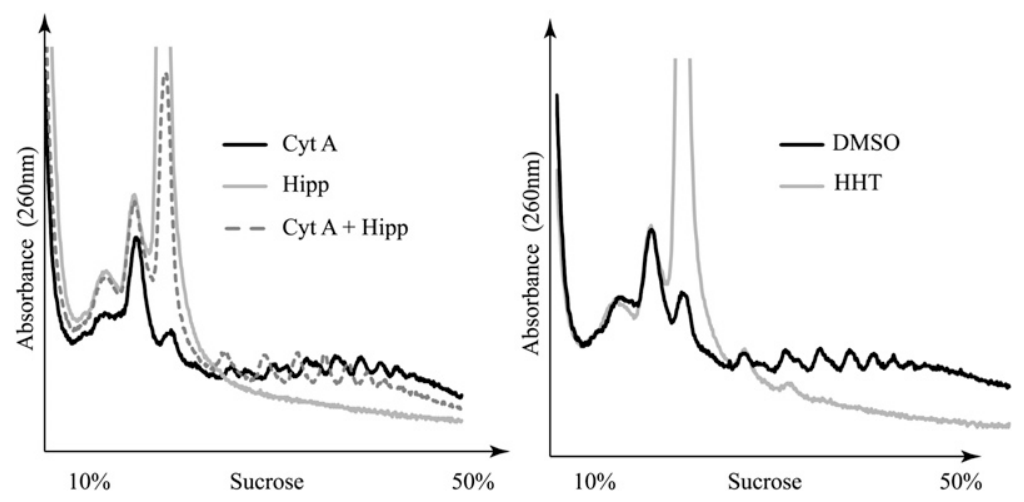

FIGURE 5. Cyt A reversibly inhibits translation in cell culture. $(A)$ Consequences of Cyt A exposure on DNA, RNA, and protein synthesis in HeLa cells. Cyt A was added to cell medium for $1 \mathrm{~h}$ and $\left[6-{ }^{3} \mathrm{H}\right]$ thymidine, $\left[5-{ }^{3} \mathrm{H}\right]$ uridine, or $\left[{ }^{35} \mathrm{~S}\right]$ methionine/cysteine was present during the last $20 \mathrm{~min}$ of incubation. Counts from TCA-precipitated material were normalized to total protein content and set relative to the DMSO control. The average of four data points is shown with the SEM indicated by error bars. (B) Inhibition of translation by Cyt A is reversible. HeLa cells were incubated in $2 \mu \mathrm{M}$ Cyt A for $1 \mathrm{~h}$, after which fresh medium lacking Cyt A was added. Twenty minutes before lysis, $\left[{ }^{35} \mathrm{~S}\right]$ methionine/cysteine was added. Normalization was performed to total protein concentration and set relative to the DMSO control. The average of four measurements is shown with the SEM represented by error bars. (C) Cyt A does not allow ribosome run-off in cell culture. Polysome formation in HeLa cells exposed to $2 \mu \mathrm{M}$ Cyt A for $1 \mathrm{~h}$ and/or $5 \mu \mathrm{M}$ Hipp for $30 \mathrm{~min}$ or $0.5 \mu \mathrm{M}$ HHT for $1 \mathrm{~h}$. Panels are from the same experiment and were separated for clarity.

Did B (Fig. 5C; Urdiales et al. 1996; Schneider-Poetsch et al. 2010). In the eEF1A-dependent aa-tRNA-binding experiment (Fig. 3C), the amount of $\left[{ }^{14} \mathrm{C}\right] \mathrm{Phe}-\mathrm{tRNA}{ }^{\text {Phe }}$ bound to ribosomes was significantly reduced in the presence of GMPPNP compared with GTP (Fig. 3C). We believe this may be due to the large dilution ( $\sim 100$-fold $)$ that occurs during processing of the samples for filter binding, allowing dissociation of the ternary complex from the ribosome. This is consistent with the finding that only after GTP hydrolysis is the charged tRNA locked in the A site (Rodnina and Wintermeyer 2001). Hence, one interpretation of our results is that in the presence of GMPPNP, the aa-tRNA is lost from the ribosome. However, this is not observed if Did B or Cyt A are present
(Fig. 3C), suggesting that these compounds stabilize the aa-tRNA:ribosome interaction, perhaps by blocking release of eEF1A. Both Cyt A and Did B inhibited translocation when aa-tRNA was loaded in an eEF1A-dependent manner (Fig. 3D; SirDeshpande and Toogood 1995), which would be consistent with this model, since eEF2 and the ternary complex share binding sites on the ribosome (Marco et al. 2004). Indeed, this mode of action has been suggested for Did B previously and is the mechanism of action of the antibiotic kirromycin (Wolf et al. 1977; Ahuja et al. 2000; Andersen et al. 2003; Schmeing et al. 2009). It remains to be determined whether Cyt A binds directly to the ribosome and/or to eEF1A.

It has recently been suggested that tumor reduction caused by eIF4F inhibition may partially be caused by inhibiting angiogenesis (Graff et al. 2007; Cencic et al. 2009). Here, we show that Cyt A can also inhibit angiogenesis as Cyt A-inhibited HUVEC tube formation (Fig. $6 \mathrm{~A}, \mathrm{~B})$ as well as microvessel development in the CAM assay (Fig. 6D) in a manner similar to Did B (Taraboletti et al. 2004). These results suggest that Cyt A merits further study, not only for hematological cancers, but also for solid tumors requiring angiogenesis for optimal growth.

\section{MATERIALS AND METHODS}

\section{Materials}

Cyt A was prepared as previously described and stored in 100\% DMSO (Kakeya et al. 1997). Didemnin B (Did B) (NCI-Developmental Therapeutics Program), homoharringtonine (HHT) (Sigma-Aldrich), and cycloheximide (CHX) (Bioshop) were stored in $100 \%$ DMSO, whereas anisomycin (Sigma) was resuspended in $\mathrm{H}_{2} \mathrm{O}$. Hippuristanol was purified as previously described (Bordeleau et al. 2006). All compounds were stored at $-80^{\circ} \mathrm{C}$.

\section{Cell culture experiments}

HeLa cells were grown in DMEM containing 10\% fetal bovine serum and $100 \mathrm{U} / \mathrm{mL}$ penicillin/streptomycin. HUVEC cells (Lonza Walkersville, Inc.) were grown in EMB-2 medium supplemented with EGM-2.

For thymidine labeling of DNA, cells were serum starved for $48 \mathrm{~h}$, followed by the addition of serum for $7 \mathrm{~h}$, at which point 
A

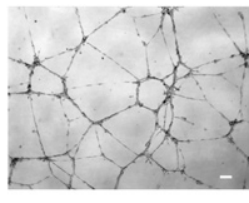

$0.5 \%$ DMSO

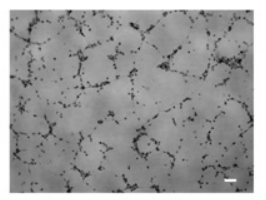

$5 \mu \mathrm{M}$ Cyt A



$0.5 \mu \mathrm{M}$ Cyt A

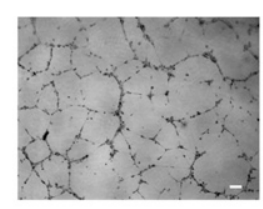

$2 \mu \mathrm{M}$ Cyt A

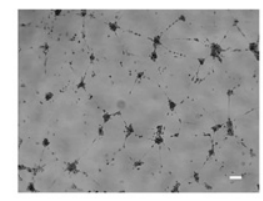

$0.2 \mu \mathrm{M}$ Silv
B
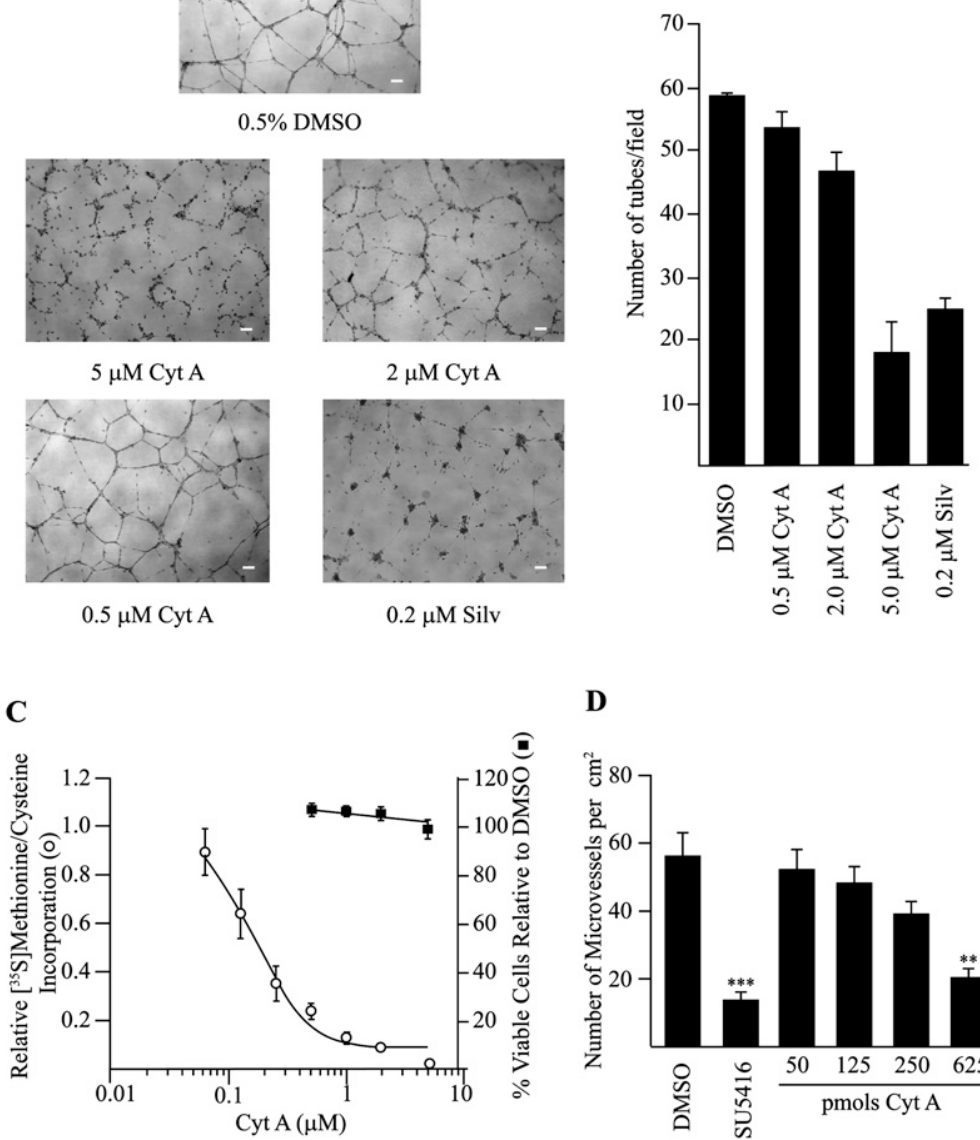

D

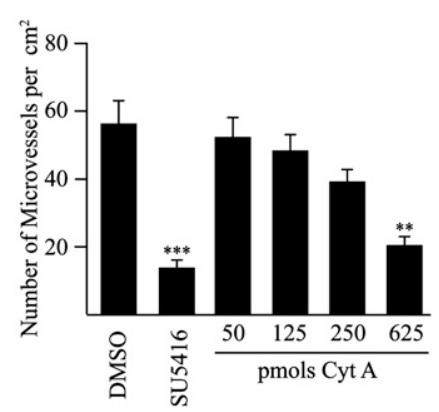

FIGURE 6. Cyt A inhibits angiogenesis. (A) Photomicrographs of HUVEC tube formation at different concentrations of Cyt A or silvestrol (Silv). Scale bar, $0.1 \mathrm{~mm}$. (B) Quantitation of tube formation in HUVECs. Each well was photographed in seven fields, and the average number of tubes formed was counted. The average of four experiments is shown. Error bars represent the SEM. (C) Cyt A inhibits protein synthesis without inducing apoptosis in HUVECs. Following a 24-h exposure to Cyt A or DMSO, HUVECs were labeled for $20 \mathrm{~min}$ with $\left[{ }^{35} \mathrm{~S}\right]$ methionine/cysteine or monitored for apoptosis. For the translation assays, TCA-precipitable material was normalized to total protein content and set relative to the DMSO control. The average of four measurements is shown with the SEM represented by error bars. Cell viability was judged by the relative percent of Annexin-FITC or propidium iodide staining compared with DMSO controls. The average of five data points is shown with the SEM represented by error bars. (D) Cyt A inhibits angiogenesis in the CAM assay. Values presented represent the average number of vessels per $\mathrm{cm}^{2}$ area for three samples with the SEM; ${ }^{\star *} P<0.01$ (vs. vehicle); ${ }^{* *} P<0.001$ (vs. vehicle).

compound was added for $1 \mathrm{~h} .\left[6-{ }^{3} \mathrm{H}\right]$ thymidine $(10 \mathrm{Ci} / \mathrm{mmol})$ (Perkin Elmer) was present for the last $20 \mathrm{~min}$ of the reaction. For RNA labeling, cells were not serum starved and $\left[5-{ }^{3} \mathrm{H}\right]$ uridine $(26.3 \mathrm{Ci} / \mathrm{mmol})$ (Perkin Elmer) was present during the last 20 min of a 1-h compound treatment. Cells were washed in PBS and lysed in RIPA buffer (50 mM Tris- $\mathrm{HCl}$ at $\mathrm{pH} 7.5,150 \mathrm{mM} \mathrm{NaCl}$, $1 \%$ NP-40, $0.5 \%$ sodium deoxycholate, $0.1 \%$ SDS). Radioactive incorporation was measured by TCA precipitation (5\% TCA) onto GF/C filters (preblocked with 5\% TCA and $0.1 \mathrm{M}$ inorganic pyrophosphate). Filters were washed with $5 \mathrm{~mL}$ of cold $1 \%$ TCA, followed by $5 \mathrm{~mL} 100 \%$ ethanol, and quantified by scintillation counting. Counts were standardized to total protein content that had been determined using the $D_{c}$ protein assay (Bio-Rad).
To monitor protein synthesis, cells were seeded into a 24-well dish and exposed to compound for $1 \mathrm{~h}$ with labeling performed during the last $20 \mathrm{~min}$ using $\left[{ }^{35} \mathrm{~S}\right]$ Easy Tag Express Protein Labeling mix (1175 Ci/ mmol) (Perkin Elmer). Cells were lysed in RIPA buffer and an aliquot processed for TCA precipitation as described above.

HUVEC tube formation assays were performed as published previously (Cencic et al. 2009). HUVECs were seeded at $100,000 \mathrm{cell} /$ well in the presence of compound on top of $300 \mu \mathrm{L}$ of solidified BD Matrigel Matrix (BD Biosciences) in a 24well dish. After $24 \mathrm{~h}$, pictures were taken using a Nikon Eclipse TE300 microscope.

\section{In vitro translation assays}

In vitro translations were performed as previously reported (Novac et al. 2004). Translations were performed using a capped bicistronic mRNA reporter $\mathrm{FF} / \mathrm{HCV} /$ Ren transcribed from $\mathrm{pSP} /(\mathrm{CAG})_{33} / \mathrm{FF} /$ HCV/Ren.pA $A_{51}$, in which firefly (FF) luciferase protein is produced by capdependent translation and Renilla (Ren) luciferase protein is generated by Hepatitis $\mathrm{C}$ virus (HCV) IRES-mediated initiation. Translation extracts were programmed with $8 \mu \mathrm{g} / \mathrm{mL}$ mRNA.

Experiments analyzing the consequences of Cyt A on actively translating ribosomes were performed in Krebs-2 extracts in the absence of in vitrotranscribed RNA, but in the presence of $\left[{ }^{35} \mathrm{~S}\right]$ methionine (Perkin Elmer), with compound being added 5 min after translation had been initiated. Aliquots $(10 \mu \mathrm{L})$ were taken at the indicated times and added to $1.1 \mu \mathrm{L}$ of $0.5 \mathrm{mM}$ cycloheximide (CHX) and placed on dry ice to stop the reaction. Reactions were spotted onto 3 MM Whatman paper that had been preblocked with $50 \times$ amino acid mix (GIBCO). Filters were incubated in $10 \%$ $\mathrm{TCA}+0.1 \%$ methionine on ice for 20 min, boiled in 5\% TCA for $15 \mathrm{~min}$, washed with $100 \%$ ethanol, dried, and the radioactivity quantitated by scintillation counting.

In vitro translation of poly(Phe) was performed in RRL using 50\% RRL (Promega), $40 \mu \mathrm{M}$ amino acid mix lacking phenylalanine, $40 \mu \mathrm{M}$ methionine, $0.1 \mu \mathrm{g} / \mu \mathrm{L}$ poly(U) RNA, $4 \mu \mathrm{M}$ magnesium acetate, $50 \mu \mathrm{M}$ potassium acetate, and $50 \mu \mathrm{Ci} / \mathrm{mL}\left[{ }^{3} \mathrm{H}\right]$ phenylalanine (Perkin Elmer). Following a 1 -h incubation at $30^{\circ} \mathrm{C}$, reactions were processed for TCA precipitation as described above.

\section{Ribosome-binding assays and polysome profiling}

Ribosome-binding assays were performed essentially as described previously (Robert et al. 2006). Briefly, compound was preincubated 
with RRL at a final $\mathrm{KCl}$ concentration of $150 \mathrm{mM}$ for $5 \mathrm{~min}$, after which ${ }^{32} \mathrm{P}$-labeled CAT mRNA was included. When a second compound was added, it was delivered $3 \mathrm{~min}$ after addition of RNA and reactions allowed to proceed at $30^{\circ} \mathrm{C}$ for $10 \mathrm{~min}$. Reactions were centrifuged through a $10 \%-30 \%$ glycerol gradient at $39,000 \mathrm{rpm}$ for $3.5 \mathrm{~h}$ in a SW40 rotor. Fractions $(0.5 \mathrm{~mL})$ were collected and quantitated by Cherenkov counting.

Polysome profiles of HeLa cells where visualized by treating cells with DMSO, $2 \mu \mathrm{M}$ Cyt A, or $0.5 \mu \mathrm{M}$ HHT for $1 \mathrm{~h}$ in a $10-\mathrm{cm}^{2}$ dish. Hippuristanol $(5 \mu \mathrm{M})$ was added during the remaining $30 \mathrm{~min}$. Cells were then washed in PBS containing $0.1 \mathrm{mg} / \mathrm{mL}$ $\mathrm{CHX}$, scraped, and lysed in hypotonic lysis buffer $(5 \mathrm{mM}$ Tris- $\mathrm{HCl}$ at $\mathrm{pH} 7.5,2.5 \mathrm{mM} \mathrm{MgCl}_{2}, 1.5 \mathrm{mM} \mathrm{KCl}, 0.1 \mathrm{mg} / \mathrm{mL} \mathrm{CHX,} 2 \mathrm{mM}$ DTT). The lysate was supplemented with $0.5 \%$ Triton X-100 and $0.5 \%$ sodium deoxycholate, centrifuged briefly $(12,000 \mathrm{~g}$ for $2 \mathrm{~min})$, and the supernatant loaded onto $10 \%-50 \%$ sucrose gradients (20 mM HEPES-KOH at $\mathrm{pH} 7.5,100 \mathrm{mM} \mathrm{KCl,} 5 \mathrm{mM} \mathrm{MgCl}_{2}$, $1 \mathrm{mM}$ DTT). Samples were centrifuged at 35,000 rpm for $2 \mathrm{~h}$ in a SW40 rotor at $4^{\circ} \mathrm{C}$. The $\mathrm{OD}_{260}$ was monitored with a UA-6 UV detector (ISCO) using a Brandel tube piercer. Data was recorded using InstaCal Version 5.70 and TracerDaq Version 1.9.0.0 (Measurement Computing Corporation).

\section{Peptidyl transferase assays}

The peptidyl transferase assay was performed as previously described (Lorsch and Herschlag 1999). Briefly, $\left[{ }^{35} \mathrm{~S}\right]$ methionyltRNA $_{i}$ was generated by incubating $0.25 \mathrm{mg} / \mathrm{mL}$ total calf liver tRNA (Novogen) with $10 \mathrm{mM}$ ATP, $10 \mathrm{mM} \mathrm{CTP}, 0.25 \mathrm{mg} / \mathrm{mL}$ leucovorin, $1 \mathrm{mCi} / \mathrm{mL}\left[{ }^{35} \mathrm{~S}\right]$ methionine, and $0.875 \mu \mathrm{g} / \mathrm{mL} \mathrm{E}$. coli aminoacyl-tRNA synthetases (Sigma) in $50 \mathrm{mM}$ sodium cacodylate ( $\mathrm{pH} 7.4$ ), $15 \mathrm{mM} \mathrm{MgCl}_{2}$, and $7 \mathrm{mM}$ 2-mercaptoethanol at $37^{\circ} \mathrm{C}$ for $30 \mathrm{~min}$ (Stanley 1974). Charged tRNA was purified by phenol/chloroform extraction, exclusion chromatography on a Sephadex G-50 spin-column, and ethanol precipitation.

Purified $40 \mathrm{~S}$ and $60 \mathrm{~S}$ ribosomes $(0.06 \mu \mathrm{M})$ (Fraser et al. 2007), $0.5 \mathrm{mM}$ GTP, $1 \mu \mathrm{M}$ model RNA (GGAA[UC] $]_{7} \mathrm{UAUG}[\mathrm{CU}]_{10} \mathrm{C}$ ), $2 \mathrm{nM}$ labeled $\left[{ }^{35} \mathrm{~S}\right]$ methionyl-tRNA $\mathrm{i}$, and a high-salt wash of ribosomes (Lorsch and Herschlag 1999) were incubated with $50 \mu \mathrm{M}$ Cyt A. Reactions were subsequently started by the addition of $0.4 \mathrm{mM}$ puromycin at $26^{\circ} \mathrm{C}$. Aliquots were stopped in $0.4 \mathrm{M}$ sodium acetate, spotted on cation-exchange IONEX-25 SA-Na TLC plates (Macherey-Nagel) (prerun in distilled water and dried), and developed in $2 \mathrm{M}$ ammonium acetate and $10 \%$ acetonitrile. Experiments were visualized by phosphorimaging (Typhoon Trio, Amersham).

\section{tRNA-binding and translocation assays}

tRNA-binding and translocation assays were performed essentially as described (SirDeshpande and Toogood 1995; Robert et al. 2006). $\left[{ }^{14} \mathrm{C}\right]$ Phe-tRNA ${ }^{\text {Phe }}$ was prepared by charging $0.2 \mathrm{mg} / \mathrm{mL}$ yeast tRNA $^{\text {Phe }}$ (Sigma) with $3.75 \mathrm{mM}$ ATP, $0.06 \mathrm{mM}\left[{ }^{14} \mathrm{C}\right]$ phenylalanine in $50 \mathrm{mM}$ Tris- $\mathrm{HCl}$ at $\mathrm{pH} 7.5,20 \mathrm{mM} \mathrm{Mg}(\mathrm{OAc})_{2}$, and $120 \mathrm{mM} \mathrm{KCl}$ using $10 \%(\mathrm{v} / \mathrm{v})$ yeast $\mathrm{S} 100$ as the source of tRNA synthetase. Charged tRNA was purified via phenol/chloroform extraction, passed through a Sephadex G-50 spin-column, followed by ethanol precipitation (Odom et al. 1990).

For eEF1A-dependent assays, reactions were performed with $1.77 \mu \mathrm{M}$ salt-washed 80 S ribosomes, $(0.4 \mu \mathrm{g} / \mathrm{mL})$ poly(U) RNA, and $0.2 \mu \mathrm{M}\left[{ }^{14} \mathrm{C}\right] \mathrm{Phe}-\mathrm{tRNA}{ }^{\text {Phe }}$ with $4.65 \mu \mathrm{g}$ of eEF1A. Either $0.15 \mathrm{mM}$ GMP-PMP, GDP, or GTP was added in HEPES buffer (20 mM HEPES at $\mathrm{pH} 7.5,10 \mathrm{mM} \mathrm{MgCl}_{2}, 100 \mathrm{mM} \mathrm{KCl}, 1 \mathrm{mM}$ DTT) and reactions $(100 \mu \mathrm{L})$ were incubated at $37^{\circ} \mathrm{C}$ for $30 \mathrm{~min}$. Aliquots (6\% of the total reaction) were taken, diluted in $0.8 \mathrm{~mL}$ of HEPES buffer and filtered through Type HA nitrocellulose filters (Millipore). Amino acyl-tRNA binding was quantitated by scintillation counting and values obtained without ribosomes were subtracted to remove background. The remaining reaction volume (of samples containing GTP) was used to perform translocation assays. Additional GTP $(1 \mathrm{mM})$ was added to $15 \%$ of the samples in the presence or absence of $0.5 \mathrm{mM}$ puromycin and/or $0.05 \mu \mathrm{g} / \mu \mathrm{L}$ eEF2 and incubated at $37^{\circ} \mathrm{C}$ for $30 \mathrm{~min}$. The reaction was quenched with $1 \mathrm{M} \mathrm{NH}_{4} \mathrm{HCO}_{3}$ and extracted with ethyl acetate. Ninety percent of the organic layer was used for quantitation by scintillation counting. A puromycin assay was performed on $10 \%$ of the original reaction to determine the amount of aminoacyl-tRNA already bound to the P-site (Wurmbach and Nierhaus 1979), which was normalized and deducted from the values obtained above to determine the total amount of tRNA translocated.

Nonenzymatic tRNA-binding reactions were performed essentially as described for eIF1A, except higher amounts of poly(U) RNA $(0.4 \mathrm{mg} / \mathrm{mL})$ were used, and the reaction was performed in the absence of both GTP (or its analogs) and eEF1A. Reactions were carried out in Tris reaction buffer $(50 \mathrm{mM}$ Tris- $\mathrm{HCl}$ at $\mathrm{pH}$ 7.5, $60 \mathrm{mM} \mathrm{KCl}, 20 \mathrm{mM} \mathrm{MgCl}_{2}$ ) containing $50 \mu \mathrm{M}$ of compound. Translocation assays were performed as described above, except that they were carried out in Tris reaction buffer.

\section{eEF1A enzymatic assays}

GTP cross-linking to eEF1A was performed in $20-\mu \mathrm{L}$ reactions containing $1 \mu \mathrm{g}$ of eEF1A and $2.5 \mu \mathrm{Ci}$ of $\left[\alpha-{ }^{32} \mathrm{P}\right] \mathrm{GTP}(3000 \mathrm{Ci} /$ $\mathrm{mmol}$ ) (Perkin Elmer) with or without $0.8 \mu \mathrm{g}$ of Phe-tRNA ${ }^{\text {Phe }}$ (Sigma) in GTPase buffer (25 mM HEPES at pH 7.5, $125 \mathrm{mM}$ $\left.\mathrm{KCl}, 8.5 \mathrm{mM} \mathrm{MgCl}_{2}, 1 \mathrm{mM} \mathrm{DTT}\right)$. Reactions were incubated at $37^{\circ} \mathrm{C}$ for $15 \mathrm{~min}$ in the presence of $50 \mu \mathrm{M}$ Cyt A, $1 \mathrm{mM}$ cold GTP competitor, or DMSO, and cross-linked using a 254-nm germicidal UV lamp at $4^{\circ} \mathrm{C}$ for $15 \mathrm{~min}$. Reactions were digested with 0.5 $\mu \mathrm{g} / \mu \mathrm{L}$ RNase A for $10 \mathrm{~min}$ at $37^{\circ} \mathrm{C}$, separated by SDS-PAGE, and visualized by autoradiography. Negative controls contained $1 \mu \mathrm{g}$ of BSA instead of eEF1A.

Electrophoretic mobility shift assays were performed in $10-\mu \mathrm{L}$ reactions in GTPase buffer using $0.5-2 \mu \mathrm{g}$ of eEF1A and $1 \mathrm{mM}$ GTP. Reactions were preincubated at room temperature for $10 \mathrm{~min}$, after which time $20,000 \mathrm{cpm}$ of $\left[{ }^{14} \mathrm{C}\right] \mathrm{Phe}-\mathrm{tRNA}{ }^{\text {Phe }}$ was added, and the incubation continued for an additional $15 \mathrm{~min}$. Equivalent molar amounts of unlabeled Phe-tRNA ${ }^{\text {Phe }}$ were used as competitor. Reactions were analyzed on $6 \%$ native polyacrylamide (29:1 acrylamide:bisacrylamide) gels and electrophoresis performed in $1 \times$ TBE (90 mM Tris, $90 \mathrm{mM}$ boric acid, $2 \mathrm{mM}$ EDTA). Gels were then treated with En $^{3}$ Hance (Perkin Elmer), washed in water, dried, and visualized by autoradiography.

GTPase assays $(20 \mu \mathrm{L})$ were performed in GTPase buffer containing $0.5 \mu \mathrm{g}$ of eEF1A and $1 \mu \mathrm{Ci}$ of $\left[\gamma^{\left.-{ }^{32} \mathrm{P}\right] \mathrm{GTP}}(6000 \mathrm{Ci} / \mathrm{mmol})\right.$ (Perkin Elmer) incubated with or without $0.8 \mu \mathrm{g}$ of unlabeled PhetRNA $^{\text {Phe }}, 16.8$ pmol 40S, and 60S ribosomal subunits, and $31.4 \mathrm{pmol}$ poly(U) RNA at $25^{\circ} \mathrm{C}$. Control reactions were also performed without eEF1A or using only eEF1A (without tRNA, ribosomes or 
RNA). Aliquots $(2 \mu \mathrm{L})$ were taken and reactions stopped in $2 \mu \mathrm{L}$ of 25 mM EDTA on ice. PEI Cellulose F TLC plates (EMD Chemicals, Inc.) were spotted with a $1.5-\mu \mathrm{L}$ sample and developed using $0.3 \mathrm{M}$ $\mathrm{NaH}_{2} \mathrm{PO}_{4} / 1 \mathrm{M} \mathrm{LiCl}_{2}$. TLCs were quantitated using phosphorimaging on a Typhoon Trio (Amersham).

\section{Viability assays}

Viability assays were performed using Annexin-FITC and propidium iodide (PI) staining. HUVECs were treated with compound for $24 \mathrm{~h}$ in a 24-well plate. Cells were washed in PBS and trypsinized. Cells, PBS washes, and cell culture medium were collected together and centrifuged at $610 \mathrm{~g}$ for $5 \mathrm{~min}$. Cell pellets were washed in PBS and resuspended in $35 \mu \mathrm{L}$ Annexin V binding buffer (10 mM HEPES-NaOH at pH 7.5, $140 \mathrm{mM} \mathrm{NaCl}, 2.5 \mathrm{mM}$ $\mathrm{CaCl}_{2}$ ). PI (Sigma) to a final concentration of $5 \mu \mathrm{g} / \mathrm{mL}$ and $1.75 \mu \mathrm{L}$ FITC Annexin V (BD Biosciences Pharmingen) were added to reactions and incubated at RT for 20 min in the dark. Samples were diluted by the addition of $200 \mu \mathrm{L}$ of Annexin V binding buffer and analyzed on a Guava Easy Cyte Plus (Millipore). Each experiment included unstained, PI-only, and Annexin V-only controls.

\section{Chorioallantoic membrane (CAM) assay}

The CAM assay was performed by Links Biosciences, LLC. Fertilized eggs were placed in an egg incubator at $37^{\circ} \mathrm{C}$ and $50 \%$ humidity. After $6 \mathrm{~d}$, the egg shell was cracked and gently opened. A $5 \times 5$-mm sterile filter paper square saturated with either $25 \mu \mathrm{L}$ of compound (50,125, 250, 625 pmol), 4.2 nmol SU5416 (Sugen, Inc.), or vehicle (2\% DMSO in PBS) was placed in areas between vessels. After $48 \mathrm{~h}$, the CAMs were isolated and fixed in methanol/ acetone. Representative images were collected by photography to permit quantitative analysis of vessel density.

\section{ACKNOWLEDGMENTS}

We thank Isabelle Harvey for technical assistance and Dr. T. Martin Schmeing for critical reading of the manuscript and insightful comments. L.L. was supported by a NSERC Alexander Graham Bell (CGSD) fellowship. This work was supported by a grant from the Canadian Cancer Society Research Institute (\#20066) to J.P. and a NIH grant (R01 GM092927) to C.F.

Received June 7, 2010; accepted September 17, 2010.

\section{REFERENCES}

Ahuja D, Vera MD, SirDeshpande BV, Morimoto H, Williams PG, Joullie MM, Toogood PL. 2000. Inhibition of protein synthesis by didemnin B: How EF- $1 \alpha$ mediates inhibition of translocation. Biochemistry 39: 4339-4346.

Andersen GR, Nissen P, Nyborg J. 2003. Elongation factors in protein biosynthesis. Trends Biochem Sci 28: 434-441.

Bordeleau ME, Mori A, Oberer M, Lindqvist L, Chard LS, Higa T, Belsham GJ, Wagner G, Tanaka J, Pelletier J. 2006. Functional characterization of IRESes by an inhibitor of the RNA helicase eIF4A. Nat Chem Biol 2: 213-220.

Cencic R, Carrier M, Galicia-Vazquez G, Bordeleau ME, Sukarieh R, Bourdeau A, Brem B, Teodoro JG, Greger H, Tremblay ML, et al. 2009. Antitumor activity and mechanism of action of the cyclo- penta[b]benzofuran, silvestrol. PLoS ONE 4: e5223. doi: 10.1371/ journal.pone.0005223.

Chan J, Khan SN, Harvey I, Merrick W, Pelletier J. 2004. Eukaryotic protein synthesis inhibitors identified by comparison of cytotoxicity profiles. RNA 10: 528-543.

Chao JR, Wang JM, Lee SF, Peng HW, Lin YH, Chou CH, Li JC, Huang HM, Chou CK, Kuo ML, et al. 1998. mcl-1 is an immediate-early gene activated by the granulocyte-macrophage colony-stimulating factor (GM-CSF) signaling pathway and is one component of the GM-CSF viability response. Mol Cell Biol 18: 4883-4898.

Crews CM, Collins JL, Lane WS, Snapper ML, Schreiber SL. 1994. GTP-dependent binding of the antiproliferative agent didemnin to elongation factor 1 alpha. J Biol Chem 269: 15411-15414.

Duncan R, Milburn SC, Hershey JW. 1987. Regulated phosphorylation and low abundance of HeLa cell initiation factor eIF-4F suggest a role in translational control. Heat shock effects on eIF4F. J Biol Chem 262: 380-388.

Floss HG, Yu TW. 2005. Rifamycin-mode of action, resistance, and biosynthesis. Chem Rev 105: 621-632.

Fraser CS, Berry KE, Hershey JW, Doudna JA. 2007. eIF3j is located in the decoding center of the human $40 \mathrm{~S}$ ribosomal subunit. Mol Cell 26: $811-819$.

Graff JR, Konicek BW, Vincent TM, Lynch RL, Monteith D, Weir SN, Schwier P, Capen A, Goode RL, Dowless MS, et al. 2007. Therapeutic suppression of translation initiation factor eIF4E expression reduces tumor growth without toxicity. J Clin Invest 117: $2638-2648$.

Heffron SE, Jurnak F. 2000. Structure of an EF-Tu complex with a thiazolyl peptide antibiotic determined at $2.35 \AA$ A resolution: Atomic basis for GE2270A inhibition of EF-Tu. Biochemistry 39: 37-45.

Heys SD, Park KG, McNurlan MA, Calder AG, Buchan V, Blessing K, Eremin O, Garlick PJ. 1991. Measurement of tumour protein synthesis in vivo in human colorectal and breast cancer and its variability in separate biopsies from the same tumour. Clin Sci 80: 587-593.

Isaacs JS, Xu W, Neckers L. 2003. Heat shock protein 90 as a molecular target for cancer therapeutics. Cancer Cell 3: 213-217.

Kahns S, Lund A, Kristensen P, Knudsen CR, Clark BF, Cavallius J, Merrick WC. 1998. The elongation factor 1 A-2 isoform from rabbit: Cloning of the cDNA and characterization of the protein. Nucleic Acids Res 26: 1884-1890.

Kakeya H, Zhang HP, Kobinata K, Onose R, Onozawa C, Kudo T, Osada H. 1997. Cytotrienin A, a novel apoptosis inducer in human leukemia HL-60 cells. J Antibiot 50: 370-372.

Kakeya H, Onose R, Osada H. 1998. Caspase-mediated activation of a $36-\mathrm{kDa}$ myelin basic protein kinase during anticancer druginduced apoptosis. Cancer Res 58: 4888-4894.

Kubota Y, Kleinman HK, Martin GR, Lawley TJ. 1988. Role of laminin and basement membrane in the morphological differentiation of human endothelial cells into capillary-like structures. J Cell Biol 107: 1589-1598.

Le Tourneau C, Raymond E, Faivre S. 2007. Aplidine: A paradigm of how to handle the activity and toxicity of a novel marine anticancer poison. Curr Pharm Des 13: 3427-3439.

Lindqvist L, Pelletier J. 2009. Inhibitors of translation initiation as cancer therapeutics. Future Med Chem 1: 1709-1722.

Lorsch JR, Herschlag D. 1999. Kinetic dissection of fundamental processes of eukaryotic translation initiation in vitro. $E M B O J \mathbf{1 8}$ : 6705-6717.

Lucas DM, Edwards RB, Lozanski G, West DA, Shin JD, Vargo MA, Davis ME, Rozewski DM, Johnson AJ, Su BN, et al. 2009. The novel plant-derived agent silvestrol has B-cell selective activity in chronic lymphocytic leukemia and acute lymphoblastic leukemia in vitro and in vivo. Blood 113: 4656-4666.

Marco E, Martin-Santamaria S, Cuevas C, Gago F. 2004. Structural basis for the binding of didemnins to human elongation factor eEF1A and rationale for the potent antitumor activity of these marine natural products. J Med Chem 47: 4439-4452.

Monks A, Scudiero D, Skehan P, Shoemaker R, Paull K, Vistica D, Hose C, Langley J, Cronise P, Vaigro-Wolff A, et al. 1991. 
Feasibility of a high-flux anticancer drug screen using a diverse panel of cultured human tumor cell lines. J Natl Cancer Inst 83: $757-766$.

Nijhawan D, Fang M, Traer E, Zhong Q, Gao W, Du F, Wang X. 2003. Elimination of Mcl-1 is required for the initiation of apoptosis following ultraviolet irradiation. Genes Dev 17: 1475-1486.

Novac O, Guenier AS, Pelletier J. 2004. Inhibitors of protein synthesis identified by a high throughput multiplexed translation screen. Nucleic Acids Res 32: 902-915.

Odom OW, Picking WD, Hardesty B. 1990. Movement of tRNA but not the nascent peptide during peptide bond formation on ribosomes. Biochemistry 29: 10734-10744.

Pelletier J, Peltz SW. 2007. Therapeutic Opportunities in Translation. In Translational Control in Biology and Medicine, (ed. MB Mathews et al.), pp. 855-895. Cold Spring Harbor Laboratory Press, Cold Spring Harbor, NY.

Quintas-Cardama A, Kantarjian H, Garcia-Manero G, O'Brien S, Faderl S, Estrov Z, Giles F, Murgo A, Ladie N, Verstovsek S, et al. 2007. Phase I/II study of subcutaneous homoharringtonine in patients with chronic myeloid leukemia who have failed prior therapy. Cancer 109: 248-255.

Quintas-Cardama A, Kantarjian H, Cortes J. 2009. Homoharringtonine, omacetaxine mepesuccinate, and chronic myeloid leukemia circa 2009. Cancer 115: 5382-5393.

Riboldi E, Musso T, Moroni E, Urbinati C, Bernasconi S, Rusnati M, Adorini L, Presta M, Sozzani S. 2005. Cutting edge: Proangiogenic properties of alternatively activated dendritic cells. J Immunol 175: 2788-2792.

Robert F, Gao HQ, Donia M, Merrick WC, Hamann MT, Pelletier J. 2006. Chlorolissoclimides: New inhibitors of eukaryotic protein synthesis. RNA 12: 717-725.

Robert F, Carrier M, Rawe S, Chen S, Lowe S, Pelletier J. 2009. Altering chemosensitivity by modulating translation elongation. PLoS ONE 4: e5428. doi: 10.1371/journal.pone.0005428.

Rodnina MV, Wintermeyer W. 2001. Fidelity of aminoacyl-tRNA selection on the ribosome: Kinetic and structural mechanisms. Annu Rev Biochem 70: 415-435.
Schmeing TM, Voorhees RM, Kelley AC, Gao YG, Murphy FV IV, Weir JR, Ramakrishnan V. 2009. The crystal structure of the ribosome bound to EF-Tu and aminoacyl-tRNA. Science 326: 688694.

Schneider-Poetsch T, Ju J, Eyler DE, Dang Y, Bhat S, Merrick WC, Green R, Shen B, Liu JO. 2010. Inhibition of eukaryotic translation elongation by cycloheximide and lactimidomycin. Nat Chem Biol 6: $209-217$.

SirDeshpande BV, Toogood PL. 1995. Mechanism of protein synthesis inhibition by didemnin B in vitro. Biochemistry 34: 9177-9184.

Stanley WM Jr. 1974. Specific aminoacylation of the methioninespecific tRNA's of eukaryotes. Methods Enzymol 29: 530-547.

Taraboletti G, Poli M, Dossi R, Manenti L, Borsotti P, Faircloth GT, Broggini M, D’Incalci M, Ribatti D, Giavazzi R. 2004. Antiangiogenic activity of aplidine, a new agent of marine origin. Br J Cancer 90: $2418-2424$.

Thornton S, Anand N, Purcell D, Lee J. 2003. Not just for housekeeping: Protein initiation and elongation factors in cell growth and tumorigenesis. J Mol Med 81: 536-548.

Urdiales JL, Morata P, Nunez De Castro I, Sanchez-Jimenez F. 1996. Antiproliferative effect of dehydrodidemnin B (DDB), a depsipeptide isolated from Mediterranean tunicates. Cancer Lett 102: $31-$ 37.

Watabe M, Kakeya H, Onose R, Osada H. 2000. Activation of MST/ Krs and c-Jun N-terminal kinases by different signaling pathways during cytotrienin A-induced apoptosis. J Biol Chem 275: 87668771 .

Wendel HG, De Stanchina E, Fridman JS, Malina A, Ray S, Kogan S, Cordon-Cardo C, Pelletier J, Lowe SW. 2004. Survival signalling by Akt and eIF4E in oncogenesis and cancer therapy. Nature 428: 332-337.

Wolf H, Chinali G, Parmeggiani A. 1977. Mechanism of the inhibition of protein synthesis by kirromycin. Role of elongation factor $\mathrm{Tu}$ and ribosomes. Eur J Biochem 75: 67-75.

Wurmbach P, Nierhaus KH. 1979. Codon-anticodon interaction at the ribosomal P (peptidyl-tRNA) site. Proc Natl Acad Sci 76: 21432147. 

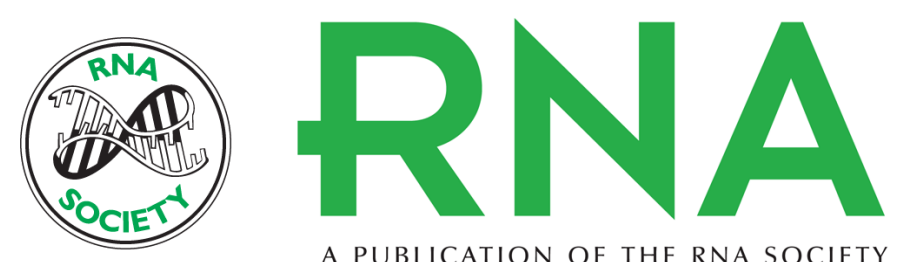

A PUBLICATION OF THE RNA SOCIETY

\section{Inhibition of translation by cytotrienin A-a member of the ansamycin family}

Lisa Lindqvist, Francis Robert, William Merrick, et al.

RNA 2010 16: 2404-2413 originally published online October 13, 2010

Access the most recent version at doi:10.1261/rna.2307710

References This article cites 44 articles, 14 of which can be accessed free at:

http://rnajournal.cshlp.org/content/16/12/2404.full.html\#ref-list-1

License

Email Alerting Receive free email alerts when new articles cite this article - sign up in the box at the Service top right corner of the article or click here. 